\title{
O ZAPOBIEGANIU KRYZYSOM W STREFIE EURO*
}

Artykuł koncentruje się na zapobieganiu kryzysom w strefie euro. Zaczynam jednak od zarządzania obecnym kryzysem, koncentrując się na jego głównych słabościach i potencjalnych kolizjach z działaniami zapobiegającymi kryzysom. Następnie rozróżniam dwa rodzaje kryzysów: finansowo-fiskalny i fiskalno-finansowy, oraz omawiam ich bezpośrednie i głębsze przyczyny. Opierając się na tej analizie, pokazuję, w jakim stopniu podjęte dotychczas działania usunęły źródła obydwu typów kryzysu.

\section{ZARZADDZANIE KRYZYSEM A ZAPOBIEGANIE KRYZYSOWI}

Intensywna i nieustająca dyskusja na temat kryzysu w strefie euro zwykle dzieli się na dwie części:

1) dyskusję na temat, jak radzić sobie z bieżącymi problemami (,zarządzanie kryzysem", ang. crisis management),

2) dyskusję na temat, jak zapobiegać pojawianiu się podobnych problemów w przyszłości, gdy już - miejmy nadzieję - obecne zostaną wyeliminowane (,zapobieganie kryzysom”). Do tej kategorii można by dodać lub potraktować jako osobne zagadnienie kwestię, co należy uczynić, aby gospodarka strefy euro lepiej radziła sobie z przyszłymi wstrząsami.

W następnej części skupię się na zapobieganiu kryzysowi, w tej chciałbym wspomnieć pewne słabości dominującego podejścia do zarządzania kryzysem w strefie euro (jeśli nie szerzej). Zwykle przyjmuje się, że reformy strukturalne, które w dłuższej perspektywie mają na celu wzmocnienie wzrostu gospodarczego, poprawę stanu finansów państwa lub zwiększenie elastyczności jego gospodarki, są konieczne lub pożądane, ale moga przynieść takie korzyści tylko w długiej perspektywie. Co zatem w krótkiej perspektywie? Pozostają wszelkiego rodzaju oficjalne kredyty ratunkowe (bail-out). W efekcie konwencjonalna dyskusja na temat krótkoterminowych środków ogranicza się do pytania, jakie instytucje maja najlepsze kompetencje do udzielanie kredytów ratunkowych i jaka ich skala jest wystarczająca, aby przynieść efekt tzw. potężnej bazooki lub

\footnotetext{
* Referat On the Prevention of Crises in the Eurozone został przedstawiony w czasie European University Conference „Governance for the Eurozone: Integration or Disintegration?”, Florence, April 26 , 2012. (Governance for the Eurozone: Integration or Disintegration?, European University Institute, Florence, Italy and Wharton Financial Institutions Center University of Pennsylvania, Philadelphia, USA, 2012. Opublikowany za zgodą wydawcy, tłumaczenie Anna M. Baziór).
} 
zapewnić wystarczająco potężną zaporę ogniową. Za tymi militarnymi lub strażackimi metaforami kryją się pewne inne metafory, jak zaraza czy efekt domina. Wyrażają one pogląd, że gdy rynki finansowe zostaną zakłócone przez kryzys w jednym kraju, będą one działać jak ślepa, gwałtowna i nikogo nieoszczędzająca siła, ,,atakując” inne kraje bez względu na ich sytuację makroekonomiczną. Z tego musi więc wynikać, że tylko potężna przeciwdziałająca siła - zmasowana interwencja państwa (tzw. potężna bazooka) może zatrzymać domniemaną dynamikę rynków finansowych.

Rynki finansowe jednak, nawet rozchwiane, nie sa ślepe. Sa w stanie rozpoznać, chociaż nie bezbłędnie i z opóźnieniem, zróżnicowaną sytuację makrogospodarczą poszczególnych państw. Dlatego też obserwujemy taką rozpiętość „spreadów” między oprocentowaniem obligacji skarbowych Niemiec i innych państw północnych a tymi wypuszczanymi na rynek przez rządy „,sprawiające problemy" w strefie euro.

Co więcej, dynamika rentowności obligacji skarbowych do pewnego stopnia odzwierciedla oczekiwania co do wyników działań państw dotkniętych kryzysem. Nie trzeba czekać na przykład na zakończenie reformy emerytalnej, żeby dostrzec krótkoterminowe korzyści w formie zmniejszonego oprocentowania obligacji rządowych. Rynki reaguja na wiarygodne zapowiedzi reform i ich wprowadzanie. Krótki przegląd państw, które szczególnie mocno zostały dotknięte przez kryzys finansowy i które ucierpiały na ogromnym wzroście odsetek obligacji skarbowych w 2009 r., jest bardzo pouczający. Jedna grupa państw: Bułgaria, Estonia, Łotwa i Litwa (tzw. grupa BELL), odczuła skok odsetek w 2009 r., po którym nastapiło ostre ich obniżenie. W drugiej grupie: Portugalia, Irlandia, Włochy, Grecja i Hiszpania (tzw. grupa PIIGS), sytuacja jest zróżnicowana - oprocentowanie obligacji Grecji i Portugalii wywindowało w górę i do tej pory nie spadło, podczas gdy zobowiązania Irlandii pokazują, przynajmniej do tej pory, dynamikę spadku. Te różnice można w większości wytłumaczyć różnicami w zakresie i strukturze reform podjętych w wymienionych państwach.

Ważnym pytaniem badawczym jest, jak rynki finansowe oceniaja spodziewane efekty różnorodnych pakietów reform w różnych warunkach początkowych. Niemniej bez wątpienia popularny pogląd, że reformy - chociaż konieczne - przynoszą korzyści dopiero $\mathrm{w}$ długiej perspektywie i w związku z tym kredyty ratunkowe sa jedynym wyjściem, należy odrzucić. Zamiast tego można zaproponować, że właściwie skonstruowane i wprowadzone pakiety reform przynoszą korzyści dwojakiej natury:

1) efe kt z a ufa ni a, który pojawia się w krótkiej perspektywie i przejawia się w obniżeniu oprocentowania obligacji skarbowych (a także obligacji podmiotów prywatnych),

2) efekty strukturalne, które zaczynaja się pojawiać po dłuższym czasie w formie zwiększonego wzrostu gospodarczego (dzięki wzrostowi zatrudnienia i/lub produkcji), obniżenia deficytu budżetowego czy elastyczniejszej gospodarki.

W dyskusji na temat zarządzania kryzysem nie należy pomijać potencjalnego konfliktu między dostępnością i wielkością kredytów ratunkowych a działaniami podejmowanymi w celu zapobiegania kryzysom. Na ten temat, szczególnie na temat pożyczek Międzynarodowego Funduszu Walutowego, jest 
dostępna obszerna literatura ${ }^{1}$. Jednakże ten problem może się pojawić w wypadku każdej formy oficjalnego kredytu ratunkowego: sama perspektywa łatwo dostępnej pożyczki kryzysowej może sprawić, że polityka gospodarcza państw stanie się mniej rozważna, a to z kolei zwiększy liczbę kryzysów wywołanych przez decyzje polityczne i liczbę pożyczek ratunkowych (moral hazard, czyli pokusa nadużycia).

Łatwy dostęp do kredytów ratunkowych może również przedłużać kryzys, który już się rozpoczął, osłabiając motywację polityków do podjęcia politycznie nieprzyjemnych, ale ekonomicznie koniecznych reform. Nawet jeśli państwo szczęśliwie ma reformatorsko nastawionego premiera, który jest odporny na to niebezpieczeństwo, to może się okazać, że jego zaplecze polityczne nie jest. Zatem łatwy dostęp do pożyczek kryzysowych może osłabiać poparcie polityczne dla przywódców reformatorów.

Obydwa rodzaje ryzyka - zwiększenia częstości występowania kryzysów wywołanych przez nierozważną politykę gospodarczą i odraczanie reform, gdy kryzysy już się zaczęły - są szczególnie duże w wypadku kredytów ratunkowych oferowanych przez banki centralne, ponieważ teoretycznie mogą one dostarczać nieograniczonych środków. W dłuższej perspektywie istnieja też inne zagrożenia i koszty tego typu kredytów ratunkowych, do których należą bańka przewartościowanych aktywów i inflacja, a także podważenie wiarygodności banku centralnego i niebezpieczeństwo jego upolitycznienia ${ }^{2}$.

I wreszcie oficjalne pożyczki kryzysowe do pewnego stopnia zastępują presję rynków finansowych presją ze strony ekspertów i polityków państw udzielających pożyczek. Nietrudno zauważyć, że ta ostatnia może przynieść nieprzyjemne skutki dla jedności europejskiej, zarówno w państwie kredytodawcy, jak i kredytobiorcy. Kredyty ratunkowe w strefie euro oficjalnie usprawiedliwiane hasłem europejskiej „solidarności” w rzeczywistości mogą ową europejską ,,solidarność” osłabić! Jest to tym bardziej prawdopodobne, jeśli pożyczki kryzysowe zmienią się w międzypaństwowe transfery finansowe lub jeśli takie transfery, usprawiedliwione sloganem ,unii fiskalnej”, zostana przedwcześnie zinstytucjonalizowane. Napięcia polityczne częściowo wywołane międzyregionalnymi transferami fiskalnymi w niektórych państwach Unii Europejskiej (jak Włochy, Hiszpania i Belgia) powinny służyć tutaj jako ostrzeżenie. Unia fiskalna w rozumieniu dużego wspólnego budżetu może być jedynie wynikiem stopniowo postępującego procesu budowy wspólnej tożsamości. Jeżeli transfery fiskalne wyprzedzaja ten naturalny proces, to go podkopią. Dotyczy to szczególnie transferów fiskalnych do państw dotkniętych kryzysem będącym

1 A. Lerrick, A. H. Meltzer, Beyond IMF Bailouts: Default without Disruption, Quarterly Economics Report, Carnegi Mellon Gailliot Center for Public Policy (May), 2001; Report of the International Financial Institutional Advisory Committee, Washington 2000; G. Dell'Ariccia, I. Schnabel, J. Zettelmeyer, Moral Hazard and International Crisis Lending: A Test, ,International Monetary Fund Working Papers" 2004 (October); O. Jeanne, J. Zettelmeyer, The Mussa Theorem (and other Results on IMF-Induced Moral Hazard), ,International Monetary Fund Working Papers” 2004 (October); N. Rubini, B. Setser, Bailouts or Bail-ins. Responding to Financial Crises in Emerging Economies, Peterson Institute for International Economics, Washington 2004; P. Manasse, N. Roubini, Rules of Thumb for Sovereign Debt Crises, ,International Monetary Fund Working Papers” 2005 (March).

${ }^{2}$ Zob. L. Balcerowicz, Eurozone I: Bail-outs are no Substitute for Reform, „Europe's World” 2012 (Spring). 
wynikiem ich własnej polityki, różniących się od transferów, których głównym celem jest pomoc w przyspieszeniu efektu konwergencji w biedniejszych państwach Unii Europejskiej (fundusz spójności). Pierwszy typ transferów, jeżeli zostanie zinstytucjonalizowany, będzie sprzyjał wypieraniu transferów drugiego typu i w ten sposób przyczyniał się do innego rodzaju napięć politycznych w łonie Unii Europejskiej, tym razem między bogatymi i biednymi (tzn. nowymi) członkami.

\section{ZAPOBIEGANIE KRYZYSOWI: DWA TYPY KRYZYSÓW, KTÓRE OZNACZAJĄ ZAGROŻENIE FINANSÓW PUBLICZNYCH}

Omawianie zagadnienia zapobiegania kryzysom warto rozpocząć od wyróżnienia dwóch typów kryzysu, które wiążą się z zagrożeniem finansów publicznych:

1) kryzys finansowy (bankowy) $\rightarrow$ kryzys fiskalny,

2) kryzys fiskalny $\rightarrow$ kryzys finansowy (bankowy).

W obydwu wypadkach bezpośrednią przyczyną kryzysu (krachu/załamania) jest wcześniejszy boom wydatkowy, to znaczy pozytywny wstrząs popytowy, podsycany przez nadmierny wzrost akcji kredytowej, która skierowana jest do prywatnych uczestników rynku (kryzysy finansowo-fiskalne) lub rządów (kryzysy fiskalno-finansowe). W tym punkcie właściwie wszyscy są zgodni. Prawdziwym spornym zagadnieniem jest źródło boomu wydatkowego. A bez precyzyjnej diagnozy tego problemu nadzieja na właściwą prewencję antykryzysowa jest niewielka i istnieje znaczne ryzyko, że zaproponowane środki nie przyniosa pozytywnych efektów lub - co gorsza - będą utrudniać ich osiągnięcie bądź będa w stanie wywołać negatywne skutki uboczne.

Przykładem kryzysu finansowo-fiskalnego jest obecna sytuacja w Hiszpanii i Irlandii, a poza Europa - w Stanach Zjednoczonych i Wielkiej Brytanii. Kryzys fiskalno-finansowy najlepiej ilustruje sytuacja w Grecji i Portugalii. Problemy fiskalne Włoch wynikaja nie tyle z rozbuchanej polityki fiskalnej w ostatnich latach, ile sa skutkiem wysokiego długu publicznego, któremu towarzyszy stagnacja gospodarcza (będąca wynikiem zaniedbania reform po stronie podaży) oraz zewnętrznych wstrząsów.

Jak pokazuje schemat 1, toczy się zasadnicza dyskusja na temat źródeł boomu kredytowego w sektorze prywatnym, które to są bezpośrednią przyczyną dalszego załamania i kryzysów finansowych. Wielu obserwatorów obwinia coś, co uznaje za immanentną niestabilność ,nieuregulowanego” sektora finansowego - wzywają więc oni do zwiększenia liczby regulacji. Jest to jednak błędny pogląd, skoro najpoważniejsze problemy pojawiaja się w najściślej uregulowanym sektorze finansów (tzn. w bankach), a badania empiryczne wskazują na błędy w polityce jako na źródło problemów boomu w sektorze prywatnym ${ }^{3}$. Poniżej przedstawiam przykładowy wykaz różnych przejawów takiej polityki:

\footnotetext{
${ }^{3}$ Więcej na ten temat, zob. L. Balcerowicz, How to Avoid Another Serious Financial Crisis, mimeo 2010; Ch. Calomiris, Banking Crisis and the Rules of the Game, National Bureau of Economic Research (October), National Bureau of Economic Research, Cambridge, MA, 2009; J. B. Taylor, Getting Off Track: How Government Actions and Interventions Caused, Prolonged, and Worsened the Financial Crisis, Hoover Institution Press, 2009.
} 


\section{Schemat 1}

Dynamika kryzysu finansowo-fiskalnego

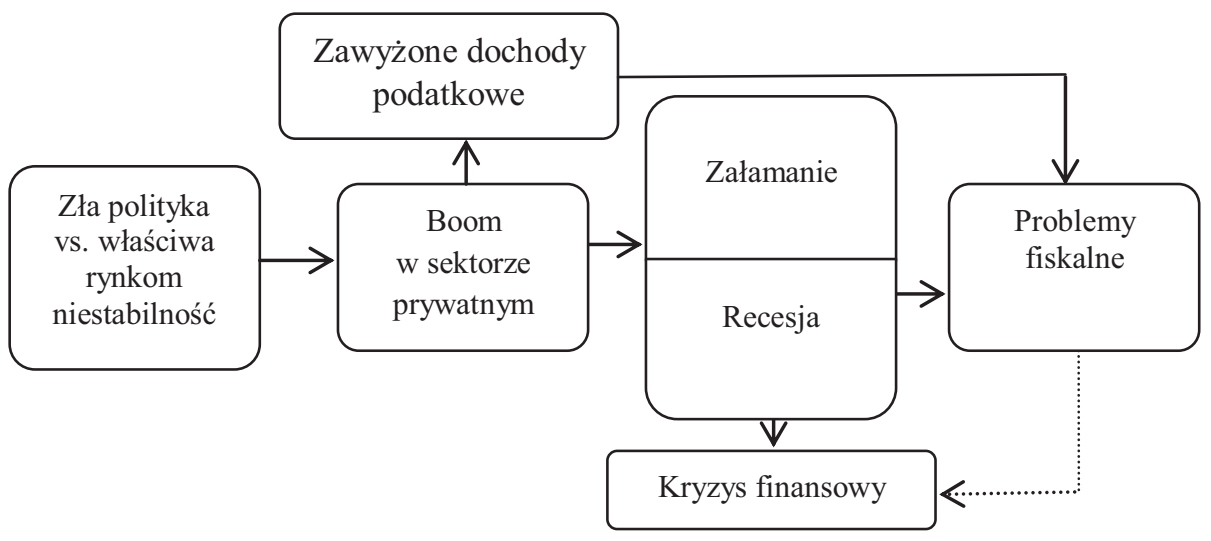

1. Upolitycznienie (czy wręcz wyznaczanie przez państwo) przeznaczenia kredytu: zwykle decydują o tym względy polityczne, które przeważają nad oceną ryzyka gospodarczego i w ten sposób prowadzą do znaczących strat bankowych i/lub zwiększenia długów państwa. Działalność funduszy Fannie Mae i Freddie Mac w Stanach Zjednoczonych czy cajas w Hiszpanii to ostatnie tego przykłady.

2. Polityka monetarna, która czasami ugina się na wietrze, to znaczy napędza bańkę przewartościowanych aktywów (polityka prowadzona przez Rezerwę Federalną w pierwszej dekadzie XXI w. to ostatni główny przykład). Takie postępowanie wiąże się z doktryną polityki monetarnej, która zawęża swój cel do krótkoterminowego indeksu cen towarów i usług (CPI) i wyłącza ze swojej sfery działań ceny aktywów i powiązane z nimi czynniki (np. wzrost podaży pieniądza na rynku i akcji kredytowej).

3. Regulacje podatkowe, które preferują finansowanie w drodze zaciągania długów zamiast powiększania kapitałów własnych firmy.

4. Subsydiowanie kredytów hipotecznych.

5. Regulacje finansowe, które zachęcają do nadmiernej sekurytyzacji wierzytelności, na przykład wagi ryzyka zawarte w regulacjach z Bazylei i obowiązkowe stosowanie przez inwestorów finansowych oceny wiarygodności kredytowej sporządzonej przez agencje ratingowe.

6. Hojne ubezpieczenia depozytów, które eliminują ważne źródło dyscypliny rynkowej.

7. Regulacje, które ograniczają koncentrację udziałów w dużych bankach i w ten sposób zwiększają tak zwane problemy agencji i osłabiają dyscyplinę rynkową ${ }^{4}$. Ten czynnik może być ważnym źródłem systemów wynagradzania menedżerów banków, które preferują krótkoterminowe cele i lekceważą długoterminowe ryzyko.

${ }^{4}$ Ch. Calomiris, op. cit. 
8. Polityka, która doprowadziła do wystąpienia syndromu ,,zbyt duży, by upaść", to znaczy subsydiowanie - w postaci premii ograniczenia ryzyka wielkich konglomeratów finansowych. Jest to kolejny przykład interwencji państwa, która osłabia dyscyplinę rynku. Istnienie takich konglomeratów powoduje, że w obliczu kryzysu finansowego wywierają one olbrzymią presję na decydentów, aby ponownie przyznali kredyty ratunkowe instytucjom finansowym, i w ten sposób przyczyniają się do powstania błędnego koła. Wspomniana polityka, obejmuje zbyt łatwą akceptację fuzji już i tak potężnych instytucji finansowych i politykę taniego pieniądza, które napędzają rozrost i tak już wielkich koncernów finansowych.

\section{KRYZYSY FISKALNO-FINANSOWE}

Problemy fiskalne, zwykle wywołane przez nadmierne wydatki budżetowe, rozszerzają się na sektor finansowy, ponieważ instytucje finansowe są znacznymi nabywcami obligacji skarbowych. Z kolei krajowe instytucje finansowe sa w posiadaniu nieproporcjonalnie dużej części długów swojego „własnego" suwerena - czego dowodem są między innymi obecne problemy greckich banków. To krajowe odchylenie (ang. home bias), czyli przywiązanie do krajowego rynku wzmacnia powiązania między kryzysami finansowymi i fiskalnymi w tych państwach.

\section{Schemat 2}

Dynamika kryzysu fiskalno-finansowego

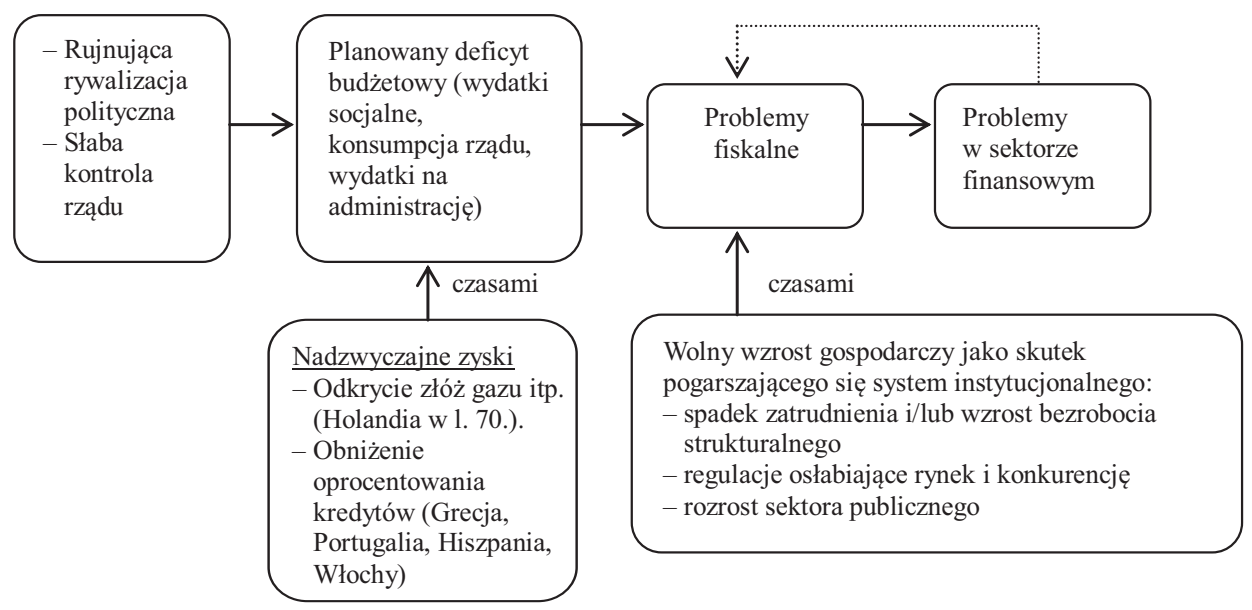

Jak pokazano na schemacie 2, nadzwyczajne korzyści lub - szerzej - łatwo dostępny pieniądz są w stanie napędzać nadmierne wydatki budżetowe i w ten sposób przyczyniają się do kryzysów fiskalnych. Gwałtowne obniżenie stóp 
procentowych, jakie uzyskały Grecja, Portugalia, Hiszpania i Włochy wraz z wejściem do Europejskiej Unii Monetarnej (European Monetary Union), należy do kategorii nadzwyczajnych korzyści.

Podstawowe pytanie brzmi: jakie siły sprawcze kryją się za tendencja do nadmiernych wydatków budżetu we współczesnych systemach politycznych? To zagadnienie należy do sfery ekonomii politycznej lub public choice. Codzienne obserwacje i badania empiryczne wskazuja na niszcząca naturę rywalizacji politycznej (walka o głosy wyborców za pomoca obietnic przyszłych wydatków) przy słabych, jeśli w ogóle jakichkolwiek, ograniczeniach wzrostu wydatków budżetu. Taka diagnoza nie powinna sugerować, że właściwym rozwiązaniem jest zakaz wolnej rywalizacji politycznej, to znaczy demokracji, ponieważ rządzący w reżimach niedemokratycznych maja skłonność do pacyfikowania nastrojów mieszkańców, zwiększając wydatki budżetu, że nie wspomnę różnych innych negatywnych konsekwencji braku społeczeństwa otwartego. Rozwiązań należy szukać w ramach systemu demokratycznego i dążyć do tego, aby konkurencja polityczna była bardziej ekonomicznie odpowiedzialna, oraz do wzmocnienia ograniczeń fiskalnych.

W wypadku pierwszego ze wskazanych problemów nic nie zastąpi większego, systematyczniejszego i bardziej profesjonalnego zaangażowania się tych części społeczeństwa obywatelskiego, które rozumieja, że indywidualna wolność i wzrost gospodarczy wymagaja powstrzymania rozrostu państwa. Przywódcy polityczni, zarówno na poziomie krajowym, jak i unijnym, powinni przynajmniej zaprzestać utożsamiania „modelu europejskiego” z hojnym (i zwykle źle zbudowanym) państwem opiekuńczym.

Z kolei drugie zagadnienie pokazuje, że konstytucyjne ograniczenie długu publicznego w stosunku do PKB i inne regulacje fiskalne są niezbędne. Dla ich wprowadzenia i utrzymania znów potrzebne jest zaangażowanie odpowiednich części społeczeństwa obywatelskiego. To zaangażowanie jest szczególnie ważne w większych krajach Unii Europejskiej, ponieważ są one mniej podatne na naciski europejskie niż mniejsze państwa - raczej to one same wywierają owe naciski. Europejska retoryka nie powinna przysłaniać istnienia Realpolitik w Unii Europejskiej. Jej godnym ubolewania przykładem było de facto unieważnienie Paktu Stabilności i Wzrostu w 2005 r. przez Niemcy i Francję.

\section{ZAPOBIEGANIE KRYZYSOWI: ZA POMOCĄ JAKICH ŚRODKÓW?}

Skoro boom wydatków (różnego rodzaju) napędzany przez wzrost kredytów to bezpośrednia przyczyna następujących w jego wyniku załamań i kryzysów, to jeśli działania zapobiegawcze maja być skuteczne, musza oddziaływać na głębsze przyczyny tego boomu. To zadanie wykracza poza granice problemów strefy euro, ale obejmuje pewne zagadnienia, które sa dla niej specyficzne.

$\mathrm{W}$ odniesieniu do boomu kredytowego $\mathrm{w}$ sektorze prywatnym przedstawiłem niepełną, ale długa listę działań, które przyczyniły się do jego wybuchu 
w przeszłości, generując wzrost zadłużenia i/lub osłabiając zdolność oceny indywidualnego ryzyka przez osoby prywatne. Zatem podstawowym pytaniem jest, w jakim stopniu inicjatywy pokryzysowe krajowych i oficjalnych instytucji publicznych wyeliminowały niebezpieczeństwo prowadzenia podobnej polityki w przyszłości. To oczywiście wymaga pogłębionej dyskusji, na którą tutaj nie ma miejsca. Odpowiem więc krótko: większość ze wskazanych wcześniej szkodliwych mechanizmów interwencjonizmu nadal działa. Obejmuja one: regulacje podatkowe, które sprzyjają deficytowi budżetowemu, zaciaganiu długów; subsydia do kredytów hipotecznych; hojne ubezpieczenia depozytów, które zastępują ważne źródło dyscypliny rynkowej, oraz regulacje ograniczające koncentrację akcji w dużych bankach, co z kolei pogłębia problemy zarządzania ładem korporacyjnym. Natomiast wśród pozytywnych oznak zmian wymieniłbym inicjatywę Bazylea III, która podnosi minimalne wymogi kapitałowe dla banków, i trwające prace nad opracowaniem sprawnych procedur upadłościowych dla dużych banków, które mają wyeliminować politykę ,,zbyt duży, by upaść”. Co do tych ostatnich, to jest jeszcze za wcześnie, by móc powiedzieć, czy te prace przyniosa konkretne praktyczne rezultaty, zwłaszcza w odniesieniu do potężnych międzynarodowych konglomeratów finansowych.

$\mathrm{Z}$ kolei niewiele się dyskutuje na temat, jak zmienić doktrynę polityki monetarnej, tak aby zmniejszyć ryzyko, że polityka pieniężna będzie od czasu do czasu uginała się na wietrze, to znaczy napędzała bańki spekulacyjne, jak to było na przykład w wypadku działań Rezerwy Federalnej i Europejskiego Banku Centralnego do czasu ostatniego kryzysu ${ }^{5}$. Co więcej, po obecnym kryzysie polityka monetarna głównych banków centralnych przesunęła się w kierunku długotrwałego utrzymywania niskich stóp procentowych, lekceważąc potencjalny negatywny wpływ takiej polityki na wzrost gospodarczy w dłuższej perspektywie $^{6}$.

Istnieje jeden szczególny problem związany z polityką monetarną strefy euro. $\mathrm{Z}$ powodu samej swej natury Europejski Bank Centralny ustala tylko jeden poziom stopy procentowej, który nie może doskonale odpowiadać sytuacji wszystkich jej różnorodnych członków. Ten problem ma aspekt czasowy i strukturalny. Pierwszy aspekt wiąże się z różnymi cyklami gospodarczymi w poszczególnych państwach, wynikającymi na przykład z asymetrycznych wstrząsów. Jak dotąd problem czasowy nie był zbyt poważny dzięki postępującej synchronizacji cyklu gospodarczego w strefie euro. Aspekt strukturalny - powszechnie ignorowany - wynika z różnych poziomów naturalnych stóp procentowych w poszczególnych krajach członkowskich, które mogą sprawiać, że stopy procentowe Europejskiego Banku Centralnego dla niektórych członków strefy euro będą zbyt niskie przez większość czasu i w ten sposób będą napędzać cykle boom-załamanie. (Irlandia i Hiszpania wydają się należeć do tej grupy). Należy zatem postawić pytanie, jakie instrumenty regulacji makroostrożnościowej (np. różnicowanie wartości kredytu hipotecznego w stosunku do wartości za-

\footnotetext{
5 Zob. J. B. Taylor, op. cit.

${ }^{6}$ Więcej na ten temat: P. Ciżkowicz, A. Rzońca, Interest Rates Close to Zero, Post-Crisis Restructuring and Natural Interest Rate, MPRA Paper nr 36989, 2012 (February).
} 
bezpieczenia) i w jakim stopniu moga neutralizować to ryzyko. To jedno $\mathrm{z}$ otwartych zagadnień technicznych związanych $\mathrm{z}$ zapobieganiem przyszłym kryzysom finansowo-fiskalnym w strefie euro.

Przejdźmy teraz do zapobiegania kryzysom fiskalno-finansowym, które wynikaja z nadmiernych wydatków budżetu, co prowadzi do narastania dużego długu publicznego. I znów ten problem wychodzi daleko poza strefę euro, ale niektóre jego aspekty sa typowe dla Europejskiej Unii Monetarnej.

W odpowiedzi na kryzys w strefie euro pojawiło się wiele inicjatyw, których celem jest zapobieganie kryzysom fiskalno-finansowym: semestr europejski, sześciopak, traktat fiskalny. Nie ma sensu omawiać ich z osobna, gdyż każdy kolejny dokument w większości obejmował poprzednie. Główne zmiany są następujące:

1) monitorowanie ex ante (poprzez naciski innych państw członkowskich) projektów budżetowych poszczególnych państw,

2) kontrola średniookresowych celów dotyczących deficytów strukturalnych,

3) większe skoncentrowanie na zredukowaniu długu publicznego w stosunku do $\mathrm{PKB}$,

4) obowiązek wprowadzenia reguł fiskalnych (hamulca długu publicznego) do konstytucji państw członkowskich.

Te zmiany z technicznego punktu widzenia, szczególnie ta ostatnia, ida w dobrym kierunku. Należy jednak pamiętać, że główną przyczyną obecnego kryzysu strefy euro nie był brak ograniczeń zawartych w traktatach, lecz fakt, że - z powodu działań sił politycznych w poszczególnych państwach członkowskich - traktaty nie były przestrzegane. Czy w przyszłości będzie inaczej, zwłaszcza wtedy, gdy - miejmy nadzieję - obecny kryzys się skończy? Niepokojącym sygnałem jest silna i skuteczna opozycja Francji przeciwko bardziej automatycznemu nakładaniu sankcji za naruszanie Paktu Stabilności i Wzrostu. A bardziej zasadniczo rzecz ujmując, uważam, że nie ma żadnego lepszego środka, który mógłby zastąić zdecydowane przesunięcie się opinii publicznej, zwłaszcza w dużych państwach strefy euro, w stronę dyscypliny fiskalnej.

Istnieją też pewne ważne luki dotyczące zmian, które wydają się niezbędne, aby zmniejszyć prawdopodobieństwo wystąpienia w przyszłości kryzysów fiskalno-finansowych. Na przykład:

- Nadmiernym wydatkom budżetu i związanemu z nimi narastaniu długu publicznego sprzyjał łatwy dostęp do pieniądza, dostarczanego przez krajowe banki, a to z kolei częściowo było wynikiem regulacji z Bazylei, które traktowały tego rodzaju pożyczki jako mniej ryzykowne (tzn. nie angażowały kapitału gwarancyjnego banków). Ta przewrotna regulacja nadal obowiązuje i włączono ja do projektu dyrektywy unijnej.

- Europejski Bank Centralny obniżył standardy zabezpieczeń dla tanich pożyczek udzielanych bankom, które z kolei pożyczają pieniądze swym rządom. Jaki byłby najlepszy sposób odejścia od tej polityki i czy zostawi ona jakiś trwały ślad?

- Zasady rachunkowości rządów Unii Europejskiej pozostawiają wiele do życzenia i do tej pory nie zostały ujednolicone. 


\title{
V. PODSUMOWANIE
}

W dominującym podejściu do obecnego kryzysu w strefie euro kładzie się nacisk na kredyty ratunkowe ze szkodą dla wysiłków na rzecz zapobiegania kryzysom. Lekceważy się $\mathrm{w}$ ten sposób czynnik zaufania, jaki niosa ze soba właściwie skonstruowane i wprowadzone reformy, i pomija potencjalny szkodliwy wpływ łatwo dostępnych i dużych kredytów ratunkowych na politykę państw dotkniętych kryzysem. W ten sposób tworzy się ryzyko, że w przyszłości liczba kryzysów będzie większa, a powstałe już kryzysy będą się przedłużały. Może to także wywołać wzrost napięć politycznych w łonie Europejskiej Unii Monetarnej.

W przeciwieństwie do popularnych wyobrażeń kryzysy finansowe (które rozszerzaja się na sferę fiskalną) nie są czystym produktem wolnego rynku, można bowiem wskazać wiele interwencji publicznych, które się do nich przyczyniły. Wiele z nich prowadzi się nadal. Jednym ze specyficznych wyzwań stojaccych przed strefa euro jest wypracowanie i wprowadzenie regulacji makroostrożnościowych, które ograniczą ryzyko baniek przewartościowanych aktywów (asset bubbles) w krajach o wyższej niż średnia naturalna stopa procentowa, to znaczy w tych, dla których stopy procentowe Europejskiego Banku Centralnego będą zbyt niskie przez większość czasu. Jest to argument przeciwko proponowanej harmonizacji regulacji makroostrożnościowych w Unii Europejskiej.

Bezpośrednią przyczyną kryzysów fiskalnych, które są pochodną kryzysów w sektorze finansów, są nadmierne wydatki budżetowe, wynikające $\mathrm{z}$ destrukcyjnej rywalizacji politycznej w obliczu słabych lub braku ograniczeń działalności fiskalnej państw. Zatem aby zapobiegać poważnym kryzysom fiskalno-finansowym, należy zająć się tą głębszą ich przyczyną. Ostatnie inicjatywy w Unii Europejskiej zdają się iść we właściwym kierunku, ale nie zastąpią one większego aktywnego zaangażowania tych części społeczeństwa obywatelskiego poszczególnych krajów, które rozumieją, że wolność jednostki i rozwój gospodarczy wymagaja aktywnego przeciwdziałania rozrostowi interwencjonizmu państwa.

prof. dr hab. Leszek Balcerowicz

Szkota Gtówna Handlowa w Warszawie

\section{ON THE PREVENTION OF CRISES IN THE EUROZONE}

\author{
Summary
}

This paper focuses on crisis prevention in the Eurozone. I start, however, with the management of the current crisis, focusing on its main weaknesses and on its potential conflicts with crisis prevention. I then distinguish between two types of crises: the financial-fiscal and the fiscal-financial, and discuss their proximate and underlying causes. Based on the analysis, I discuss to what extent the initiatives taken so far have removed the root causes of both types of crisis. 
Copyright of Journal of Law, Economics and Sociology is the property of Faculty of Law and Administration of Adam Mickiewicz University in Poznan and its content may not be copied or emailed to multiple sites or posted to a listserv without the copyright holder's express written permission. However, users may print, download, or email articles for individual use.

Właścicielem praw autorskich do „Ruchu Prawniczego, Ekonomicznego i Socjologicznego” jest Wydział Prawa i Administracji Uniwersytetu im. Adama Mickiewicza w Poznaniu. Zawartość czasopisma nie może być kopiowana, przesyłana do innych stron internetowych bądź zamieszczana na blogach bez pisemnej zgody wydawcy. Niemniej artykuły można drukować, kopiować lub przesyłać w formie elektronicznej na własny użytek. 